\title{
Effectiveness of the sanitation regimes used by dairy actors to control microbial contamination of plastic jerry cans' surfaces
}

\author{
Wanjala Nobert Wafula ${ }^{1 *}$, Wafula Joseph Matofari ${ }^{1}$, Masani John Nduko ${ }^{1}$ and Peter Lamuka ${ }^{2}$
}

\begin{abstract}
Background: The most common milk handling containers used by dairy actors along the informal milk value chain in developing countries are plastics jerry cans which are difficult to effectively be cleaned thus contributing immensely to milk contamination and consequently post-harvest losses. The aim of this study was to determine the effectiveness of some common cleaning regimes used by the dairy actors in Kenya against reduction of surface microbial load on jerry cans. Milk handling plastic jerry can containers $(n=16)$ were obtained from dairy actors and then subjected to four different commonly used cleaning regimes alongside a control experiment of aluminium cans $(n=4)$. These containers were aseptically swabbed in three replicates before and after the application of a cleaning regime and the swabs $(n=120)$ analyzed for Total Viable Count (TVC), Total Coliform Count (TCC) and Lactic Acid Bacteria (LAB). The quantitative mean difference of the bacterial load reduction between before and after the application of a cleaning regime was used as the measure of its effectiveness.

Results: The study found out that irrespective of the cleaning, the type of container was significant $(P<0.001)$ in the reduction of microbial contaminants, whereby the aluminium cans had the highest microbial load reduction of 86,85 and $96 \%$ for TVC, TCC and LAB respectively as compared to 40, 28 and $42 \%$ for TVC, TCC and LAB respectively for plastic jerry cans. The use of a commercial scourer in the cleaning was found to significantly reduce $(P<0.05)$ only TVC and TCC.

Conclusions: The results from this study explains the unsuitability of plastic jerry cans in handling of milk and a risk factor for milk post-harvest losses in Kenya through microbial contamination.
\end{abstract}

Keywords: Plastic jerry cans, Contamination, Post-harvest losses, Nakuru

\section{Background}

Milk from the mammary glands of healthy animals is initially sterile, but post-harvest handling like the milking personnel and milk handling containers; remain to be the major sources of bacterial contamination of raw milk (Coorevits et al. 2008; Reta et al. 2016). Therefore, milk should be produced under hygienic conditions so as to meet set standards (Ahmad et al. 2015) which are $<10^{6}$ colony forming units $/ \mathrm{ml}$ in the case Kenya (KEBS 2010). However, the procedures used in cleaning and sanitizing the milk handling equipments are also key factors in influencing the level of microbial

\footnotetext{
*Correspondence: blessednobert@yahoo.com

'Department of Dairy and Food Science and Technology, Egerton University, P.O. Box 536-20115, Egerton, Kenya

Full list of author information is available at the end of the article
}

contamination of raw milk in terms of counts and the types of bacterial (Kelly et al. 2009).

Milk should be handled in hygienically designed equipment i.e. one that has no dead spaces and crevices, the major control method of surface route of milk contamination, is the use of an effective cleaning and disinfection programme. Failures in the cleaning and disinfection regimes will causes bacterial deposits on the container surfaces thus incubation site for them (Reinemann et al. 2003). In particular, dead ends, corners, joints, valves and the hard-to-reach places of milk handling equipment are the most appropriate regions for the existence of microbial contaminants. Bacteria attach on milk handling equipment surfaces either as single cells or in binary biofilms, which may become difficult to remove (Lindsay et al. 2002). The presence of crevices and scratches on equipment surfaces causes accumulation of organic debris that 
offers good condition for bacterial growth thus high concentration of microbial load whereby some withstand the cleaning and disinfection (Murphy and Boor 2000). Residual bacteria on surfaces that remain after cleaning and disinfection have the potential to proliferate and cause problems in the dairy value chain. Therefore the hygiene of equipment surfaces definitely affects the quality and safety of the milk and milk products to the public (Olivier and Moshoeshoe 2012).

A very wide range of plastics are available but it's only a few of them that are food grade approved such as polypropylene (PP), polycarbonate (PC), high-density polyethylene (HDPE), unplasticized polyvinyl chloride (PVC), and fluoropolymers such as polytetrafluoroethylene (PTFE, Teflon ${ }^{\oplus}$ ). Some of these plastics are porous and lack resilience and must thus be used with carefully (Faille and Carpentier 2009). Common for most dairy actors' milk handling containers in many developing countries are the plastic jerry cans and plastic buckets.

These plastic jerry cans and buckets have been reported to be used in many areas including Kenya (Omore et al. 2005), Burkina Faso (Millogo et al. 2010), Ethopia (Welearegay et al. 2012; Worku et al. 2014), Mali (Bonfoh et al. 2006), Tanzania (Kivaria et al. 2006), Turkey (Tasci 2011), Peru (Fuentes et al. 2014) Iran (Fadaei 2014) and Zimbabwe (Gran et al. 2002) among many more countries. Plastic jerry cans are more complicated to clean than aluminium cans because of the small opening (Kivaria et al. 2006). The common methods of cleaning milk handling equipments throughout the dairy value chain are use of a bar soap either with hot water, warm water or cold water and sometimes use of a commercial scourer (Orregard 2013). However there are no guidelines especially in Kenya on the use of this bar soaps and commercial scourers in the sanitation of the milk handling containers. Also, no studies have carried out in these areas where the plastic jerry cans are used to handle milk against how effective they are the sanitation practices. This study focused on the evaluating the effectiveness of the cleaning regimes commonly used by dairy actors in Kenya in sanitation of plastic jerry cans against reduction of surface microbial contaminants.

\section{Methods}

\section{Study area}

This cross-sectional study was conducted between March to October 2015 in two different areas of Nakuru County. The two areas were Olenguruone in Kuresoi subcounty ( $\left.0^{\circ} 34^{\prime} 60^{\prime \prime} \mathrm{S}, 35^{\circ} 40^{\prime} 60^{\prime \prime} \mathrm{E}\right)$ and Bahati/Wanyororo in Bahati sub-county $\left(0^{\circ} 9^{\prime} 0^{\prime \prime} \mathrm{S}, 36^{\circ} 7^{\prime} 0^{\prime \prime} \mathrm{E}\right)$. Nakuru county has an altitude of $2490 \mathrm{~m}$ above sea level, rainfall of $600 \mathrm{~mm} /$ year and temperature range of $7-25{ }^{\circ} \mathrm{C}$. Analysis of the samples was done at Egerton University, Food Microbiology laboratory.

\section{Sampling and sample preparation}

A total of sixteen plastic jerry can milk handling containers were randomly obtained from dairy actors: dairy farmers, milk transporters and milk vendors and four aluminium cans from a dairy plant (Guildford Dairy) and transported to the laboratory under aseptic conditions for microbial load analysis at $4{ }^{\circ} \mathrm{C}$. The plastic jerry were cut open and then surface swabs for collecting microorganisms were done using a sterile cotton swab buds pre-wetted in peptone water at an area of $5 \times 5 \mathrm{~cm}$ in three replicates. The replicates were from the same obtained milk container (aluminum cans and plastic jerry cans) at randomly selected different places. Swabs were taken before and after a cleaning regime by rotating the cotton end in contact with the prepared milk handling container surfaces before and after a cleaning regime. The swabbed samples were then transferred to the $9 \mathrm{ml} 0.1 \%(\mathrm{w} / \mathrm{v})$ buffered peptone water and shaken using a vortex for $2 \mathrm{~min}$ to dislodge the bacteria.

\section{Experimental design of the cleaning regimes on the plastic jerry cans}

This study was conducted in a completely randomized design in a $5 \times 2$ factorial arrangement where the plastic jerry cans and the control were subjected to different treatments with or without interaction with the use of a commercial scourer as shown in Table 1. The commercial scourer was placed in the milk containers during the washing together with the bar soap and water (cold, warm or hot), closed with the lid and shaken vigorously for $2 \mathrm{~min}$. After the cleaning the milk containers were either only rinsed or disinfected. The containers were then inverted on a rack in the sun to dry. Each treatment is one of the common sanitation practice (Wafula et al. 2016) used by the dairy actors in Kenya for the sanitation of milk containers and the surface swabs were taken before and after application of the treatment A total of sixty surface swabs were obtained from the ten treatments used on the twenty milk handling containers (plastic jerry cans $(n=16)$ and aluminium cans $(n=4)$ ) and in three replicates for microbial analysis.

The control milk container were aluminium cans were washed, rinsed and disinfected with a chlorine based disinfectant at a concentration of $300 \mathrm{ppm}$ as shown in Table 1. For the treatment with disinfection, it was applied after the cleaning of the aluminium cans and two plastic jerry cans with bar soap and commercial scourer. The contact time between the rinsed container and the disinfectant was $3 \mathrm{~min}$. After drying, swabbing was done using sterile pre-wetted swabs to collect microorganisms on the surfaces. The swabbed samples were serially diluted in buffered peptone water and cultured in the same regime as plastic jerry can containers surface swabs. 
Table 1 The treatments used in the sanitation of milk handling containers

\begin{tabular}{|c|c|c|c|c|c|c|c|c|}
\hline \multicolumn{6}{|c|}{ Treatment (Factor A) } & \multicolumn{3}{|l|}{ Factor (B) } \\
\hline \multicolumn{2}{|c|}{ Regime } & \multirow{2}{*}{$\begin{array}{l}\text { Container } \\
\text { Aluminium }\end{array}$} & \multirow{2}{*}{$\begin{array}{l}\text { Bar soap } \\
\text { Yes }\end{array}$} & \multirow{2}{*}{$\begin{array}{l}\text { Disinfectant } \\
\text { Yes }\end{array}$} & \multirow{2}{*}{$\begin{array}{l}\text { Water temperature } \\
45^{\circ} \mathrm{C}\end{array}$} & \multirow{2}{*}{$\begin{array}{l}\text { Commercial scourer } \\
\text { Yes }\end{array}$} & \multirow{2}{*}{$\begin{array}{l}\text { No. of containers } \\
2\end{array}$} & \multirow{2}{*}{$\begin{array}{l}\text { Reps } \\
3\end{array}$} \\
\hline 1 & $a$ & & & & & & & \\
\hline & $b$ & Aluminium & Yes & Yes & $45^{\circ} \mathrm{C}$ & No & 2 & 3 \\
\hline \multirow[t]{2}{*}{2} & a & Plastic & Yes & Yes & $45^{\circ} \mathrm{C}$ & Yes & 2 & 3 \\
\hline & $b$ & Plastic & Yes & Yes & $45^{\circ} \mathrm{C}$ & No & 2 & 3 \\
\hline \multirow[t]{2}{*}{3} & a & Plastic & Yes & No & $22^{\circ} \mathrm{C}$ & Yes & 2 & 3 \\
\hline & $b$ & Plastic & Yes & No & $22^{\circ} \mathrm{C}$ & No & 2 & 3 \\
\hline \multirow[t]{2}{*}{4} & a & Plastic & Yes & No & $45^{\circ} \mathrm{C}$ & Yes & 2 & 3 \\
\hline & $\mathrm{b}$ & Plastic & Yes & No & $45^{\circ} \mathrm{C}$ & No & 2 & 3 \\
\hline \multirow[t]{2}{*}{5} & $\mathrm{a}$ & Plastic & Yes & No & $85^{\circ} \mathrm{C}$ & Yes & 2 & 3 \\
\hline & $b$ & Plastic & Yes & No & $85^{\circ} \mathrm{C}$ & No & 2 & 3 \\
\hline
\end{tabular}

\section{Microbial analysis}

For total plate count, swabbed samples were serially diluted appropriately in buffered peptone water. The dilutions were then plated using pour plate method on Plate Count Agar (PCA) (Oxoid, UK) at $37{ }^{\circ} \mathrm{C}$ for $48 \mathrm{~h}$. The dilutions giving the expected total number of colonies (30-300) on a plate were selected (Richardson 1985) and the colony counting was made using Dr. N. Gerber digital colony counter (Schneider and Co., Zurich) and counts recorded. For Total Coliform Count (TCC) were surface swabs pour plated on Violet Red Bile Agar (Oxoid, UK) and incubated at $36{ }^{\circ} \mathrm{C}$ for $24 \mathrm{~h}$ on and typical dark red colonies on the plates was considered as coliforms and counted. For lactic acid bacteria (LABs) surface swabs were also serially diluted following similar methods as for total bacterial count but the dilutions were pour plated on MRS (Oxoid, UK) agar then incubated at $37 \pm 2{ }^{\circ} \mathrm{C} / 48 \mathrm{~h}$.

The colonies were further isolated and identified according to their morphological, physiological and biochemical tests characteristics. The tests that were carried out were Gram reaction test, catalase test, oxidase test, and methyl-red test (MR), Voges-proskauer test (VP), Indole test and sugar fermentations. The sugars used for testing of the fermentation of the isolates were sucrose, galactose, glucose, lactose and mannitol (Grainger et al. 2001). Sugar fermentation and gas production was considered as sufficient evidence for the presence of coliforms (Ombarak and Elbagory 2014). For the TCC, a confirmatory test by transferring $1 \mathrm{ml}$ of the aliquots from each dilution into three tubes of Lauryl sulfate tryptose (LST) broth and incubating at $35{ }^{\circ} \mathrm{C}$ for $48 \mathrm{~h}$ was also done. While for the LABs, colonies were further determined by their ability to grow at $15{ }^{\circ} \mathrm{C}, 35{ }^{\circ} \mathrm{C}$ and $45{ }^{\circ} \mathrm{C}$ for 5 days and in $\mathrm{NaCl}$ at 2, 4 and $6.5 \%$ strength in MRS broth. The growth of LAB at the different temperatures and salt concentrations was visually confirmed by turbidity changes in the MRS broth after 24, 48 and 72 h (Azadnia and Khan 2009).

\section{Statistical analysis}

Data obtained from the difference in microbial counts (TBC, TCC and LAB) between before and after application of the treatment were transformed to logarithmic values $\left(\log _{10}\right)$ of colony forming units per $\mathrm{cm}^{2}\left(\mathrm{cfu} / \mathrm{cm}^{2}\right)$ before statistical analysis. Logarithmic transformations were applied to the data to meet the assumptions of analysis of variance (ANOVA) using Komolgorov-Smirnoff's test was used to test the normality and Levene's test to test the homogeneity of variances (Goberna et al. 2005). ANOVA was analyzed using General Linear Model (PROC GLM) procedure, Komolgorov-Smirnoff's test was done using PROC NPAR1WAY procedure and Levene's test done using PROC GLM with LEVENE,s option in SAS software version 9.1. Treatments means separations were done using Least Significant Difference (LSD) at $P \leq 0.05$. Also planned orthogonal contrast method was done for the comparisons of means among the treatments.

\section{Results}

The effect of milk container type on the surface microbial load reduction

The effect of milk handling container type on the surface microbial load reduction for TVC, TCC and LAB is shown in Table 2.

The study found out that irrespective of the treatment, the overall microbial reduction was very high on aluminium milk handling containers by 86,85 and $96 \%$ for TVC, TCC and LAB respectively, as compared to plastic milk handling containers that was 36, 28 and $42 \%$ for TVC, TCC and LAB respectively. After the cleaning, aluminium container surfaces had a mean microbial residual load of $0.82 \pm 0.88,0.70 \pm 0.25$ and $0.13 \pm 0.08 \log _{10} \mathrm{cfu} / \mathrm{cm}^{2}$ while the plastic jerry cans had a 
Table 2 Comparison of mean reduction in microbial load between the aluminium milk handling cans (Control) and plastic milk handling jerry cans

\begin{tabular}{|c|c|c|c|c|c|c|}
\hline $\begin{array}{l}\text { Type of the } \\
\text { equipment }\end{array}$ & $\mathrm{N}$ & $\begin{array}{l}\text { Type of microorganism } \\
\left(\text { mean } \log _{10} \mathrm{cfu} / \mathrm{cm}^{2}\right)\end{array}$ & $\begin{array}{l}\text { Initial microbial } \\
\text { load }\end{array}$ & $\begin{array}{l}\text { Final microbial } \\
\text { load }\end{array}$ & $\begin{array}{l}\text { Change in microbial } \\
\text { load }\end{array}$ & $\begin{array}{l}\% \text { Microbial load } \\
\text { reduction }\end{array}$ \\
\hline \multirow[t]{3}{*}{ Aluminium } & 12 & TVC & $5.86 \pm 0.92$ & $0.82 \pm 0.34$ & $5.06 \pm 0.88$ & 86.3 \\
\hline & 12 & TCC & $4.53 \pm 1.17$ & $0.70 \pm 0.25$ & $3.83 \pm 1.02$ & 84.5 \\
\hline & 12 & $\angle A B$ & $3.77 \pm 0.74$ & $0.13 \pm 0.08$ & $3.60 \pm 0.77$ & 95.5 \\
\hline \multirow[t]{3}{*}{ Plastic } & 48 & TVC & $5.99 \pm 1.03$ & $3.84 \pm 0.92$ & $2.50 \pm 0.66$ & 35.9 \\
\hline & 48 & TCC & $5.07 \pm 0.91$ & $3.64 \pm 0.80$ & $1.43 \pm 0.68$ & 28.2 \\
\hline & 48 & $L A B$ & $4.81 \pm 0.81$ & $2.75 \pm 1.07$ & $2.03 \pm 0.87$ & 42.2 \\
\hline
\end{tabular}

Key: TVC total viable count, TCC total coliform count and $L A B$ lactic acid bacteria

mean microbial residual load of $3.84 \pm 0.92,3.64 \pm 0.80$ and $2.75 \pm 1.07 \log _{10} \mathrm{cfu} / \mathrm{cm}^{2}$. The mean microbial load reduction on the aluminium type of milk handling containers was significantly higher $(P<0.001)$ than on plastic jerry cans and therefore the type of the container had an influence on the effectiveness of the sanitation process.

\section{The effect of the treatments on the reduction of surface microbial load}

The effect of different treatments applied on the milk handling containers on the reduction of surface microbial load for TVC, TCC and LAB is shown in Table 3.

The study found out a significant difference $(P<0.05)$ among the treatments used in the experiment for reduction of all microbial types (TVC, TCC and LAB). There was only a significant difference $(P<0.05)$ in the use of a commercial scourer for reduction of TVC and TCC in Table 3. Also the interaction effect of the use of commercial scourer with different treatments was found to be significant $(P<0.001)$ in the reduction of TVC and TCC. Though not significant $(P>0.05)$, the overall mean reduction of the $\mathrm{LAB}$ was higher where commercial scourer was not used i.e. $2.39 \pm 1.06 \log _{10} \mathrm{cfu} / \mathrm{cm}^{2}$ when compared where it was used i.e. $2.31 \pm 1.07 \log _{10} \mathrm{cfu} /$ $\mathrm{cm}^{2}$ as shown in Fig. 1 and Table 3. The study found out that though there was no significant difference $(P<0.05)$ in $\mathrm{LAB}$ reduction among the regimes, but the interaction effect of the treatment and use of a commercial scourer had the highest microbial load reduction on the

Table $\mathbf{3}$ The analysis of variance's mean of squares table for the reduction of microbial load from surfaces of the milk containers

\begin{tabular}{lllll}
\hline Source of variation & DF & TVC & TCC & LAB \\
\hline Treatment & 4 & $20.319^{* * *}$ & $14.299^{* * *}$ & $12.520^{* * *}$ \\
Commercial scourer & 1 & $0.699^{*}$ & $0.432^{*}$ & $0.103^{\text {ns }}$ \\
Treatment* Commercial scourer $^{* * *}$ & 4 & $3.575^{* * *}$ & $3.405^{* * *}$ & $0.635^{\text {ns }}$ \\
Replication & 2 & 0.061 & 0.405 & 0.247 \\
Error & 50 & 0.269 & 0.349 & 0.267 \\
\hline
\end{tabular}

Key: C.V coefficient of variation, S.D standard deviation and $R^{2}$ coefficient of determination ns not significant at $P=0.05$, *significant at $P<0.05$,

**significant at $P<0.01$ and ${ }^{* * *}$ significant at $P<0.001$ aluminium cans and regime where the disinfectant was used by 98 and $65 \%$ respectively. However, in the regime that used the disinfectant, there was a marginally high reduction of bacteria where the commercial scourer was not used than where it was used. There are very high chances that the commercial scourer used in the cleaning is the one introducing the microorganisms.

The effect of the use of a commercial scourer during cleaning of the milk handling containers on the reduction of surface microbial load for TVC, TCC and LAB are shown in Fig. 1. The study found out that the treatments that used a commercial scourer in the cleaning had significantly $(P<0.05)$ less microbial reduction as compared to treatments that did not use the commercial scourer for the TVC and TCC but did not differ significantly $(P>$ $0.05)$ for the reduction of the LAB. The use of a commercial scourer in the cleaning of the aluminium containers had the highest reduction of the LAB and lowest for TVC whereas TCC remained almost the same to when compared to the cleaning of the aluminium cans without a commercial scourer. However on plastic jerry cans, use of the commercial scourer had a least microbial reduction of TVC, TCC and LAB when compared to where it was not used. Though the LAB were the type of bacteria had the highest reduction on plastic jerry cans, the plastic jerry cans that were cleaned without the commercial scourer had a reduction of $44.9 \%$ for the LAB when compared to the jerry cans that were cleaned with a commercial scourer that had a reduction of $39.5 \%$.

The effect of cold, warm and hot water in the cleaning of the aluminium cans and plastic Jerry cans on the reduction of surface microbial load for TVC, TCC and LAB are shown in Table 4.

The study found out that the irrespective the temperature of water for sanitation, aluminium cans had significantly $(P<0.001)$ much higher microbial load reduction from the surfaces when compared to the plastic jerry cans for TVC, TCC and LAB. The mean reduction of the $\mathrm{LAB}$ on the plastic jerry cans treated with a disinfectant was not significantly different $(P>0.05)$ from the control but significantly different $(P<0.01)$ from 


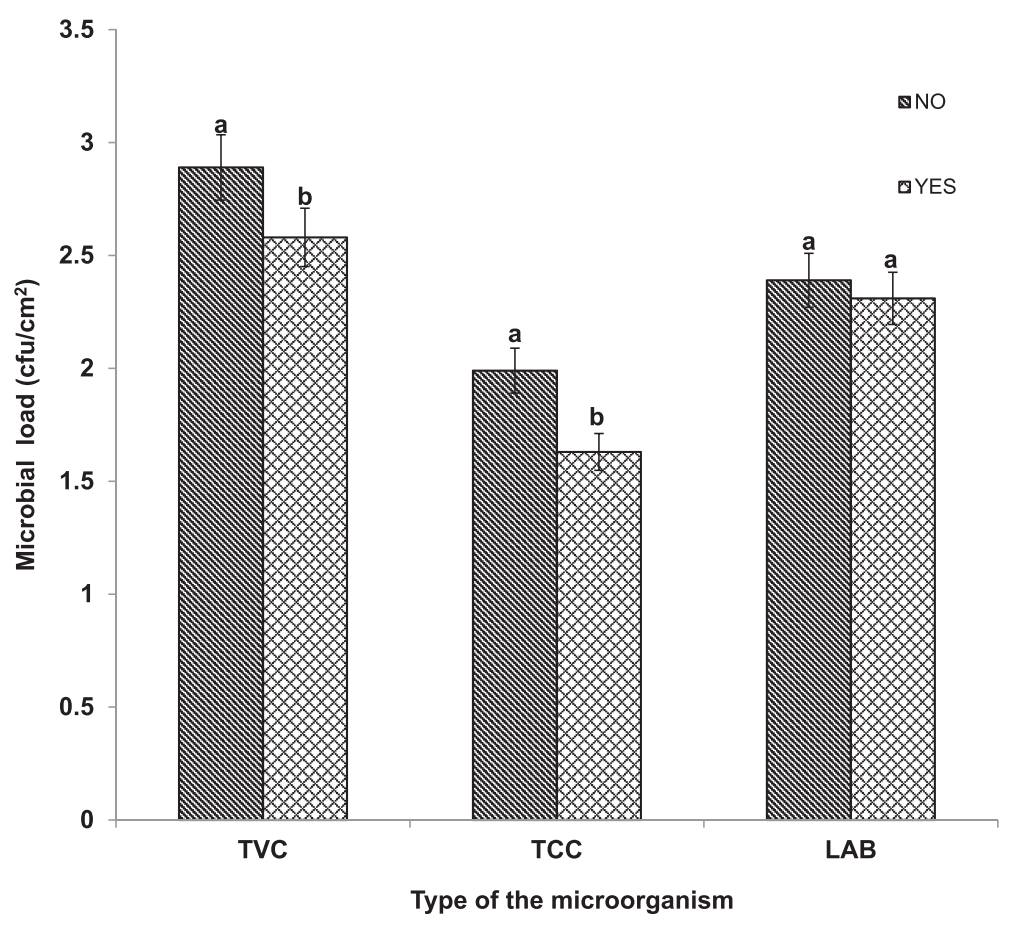

Fig. 1 Effect of the use of a commercial scourer on the reduction of surface microbial loads. Key: TVC- Total Viable Count, TCC- Total Coliform Count and LAB- Lactic Acid Bacteria. Error bars with same letter are not significantly different at $P=0.05$ using Least Significant Difference (LSD) for mean \pm standard deviation of sixty swabs taken from twenty milk container samples in three replicates

treatments with hot water, warm water and cold water. The treatments with warm water had the least reduction of the LAB while the treatments with hot water had the least reduction of the TCC.

It was found out in this study (Table 5) that the lethality of the disinfectant was very high on aluminium cans by 59,69 and $66 \%$ for TVC, TCC and LAB respectively than on the jerry can containers given the same conditions of cleaning. This can be due to presence of more biofilms on jerry cans than on aluminum cans that shield the disinfectant from accessing the microorganisms. It was also found out that the use of hot water was highly lethal on LAB, which is gram positive on both aluminium and jerry cans. This can be due to the susceptibility nature

Table 4 The mean comparison of microbial reduction from milk container surfaces between the control treatment and the treatments that used cold water, warm water, hot water and use of a disinfectant

\begin{tabular}{llll}
\hline Treatments of sanitation regimes & TVC & TCC & LAB \\
\hline The control treatment & $5.06^{\mathrm{a}}$ & $3.83^{\mathrm{a}}$ & $3.60^{\mathrm{a}}$ \\
The treatments having Hot water & $2.30^{\mathrm{b}}$ & $1.18^{\mathrm{c}}$ & $1.87^{\mathrm{b}}$ \\
The treatments having Cold water & $2.14^{\mathrm{b}}$ & $1.74^{\mathrm{b}}$ & $1.79^{\mathrm{b}}$ \\
The treatments having Warm water & $2.09^{\mathrm{b}}$ & $1.49^{\mathrm{bc}}$ & $1.22^{\mathrm{c}}$ \\
The treatments having Disinfectant & $2.08^{\mathrm{b}}$ & $1.30^{\mathrm{bc}}$ & $3.24^{\mathrm{a}}$ \\
\hline
\end{tabular}

Key: Means with the same letter (along the column) is not significantly different at $P<0.05$ using $L S D$ least significant difference of gram positives as a result of having a single cell membrane as compared to gram negatives that have an extra cellular membrane that offers resistance. When milk is put in these containers, the microorganisms in the biofilm move out so as to access the nutrients. This results in the higher milk contamination of the plastic jerry cans when compared to the aluminium cans.

\section{Discussion}

The study found out that the microbial load reduction on the aluminium cans was significantly higher than on plastic jerry cans and therefore the type of the container had an impact on the effectiveness of the sanitation process. In addition, it was found out that irrespective of the temperature of water used for sanitation, aluminium cans still had significantly much higher microbial load reduction from the surfaces when compared to the plastic jerry cans. The lethality of the disinfectant was also higher than the on aluminium cans. Similar studies had found out that aluminium cans are more hygienic in handling milk when compared to the plastic jerry cans (Omore et al. 2005). The efficacy of the sanitation programme is assessed by the reduction of microbial load on a surface, as taken before and after cleaning and disinfection (Gibson et al. 1999), and the one with high death rate or high percent reduction of microbial load is considered to be of high efficiency (Salustiano et al., 
Table 5 The effect of using a commercial scourer on the reduction of microbial load from the aluminium cans and plastic jerry can surfaces

\begin{tabular}{|c|c|c|c|c|c|c|c|}
\hline $\begin{array}{l}\text { Milk container } \\
\text { type }\end{array}$ & Scourer & $N$ & $\begin{array}{l}\text { Type of microorganism } \\
\text { (mean } \log _{10} \mathrm{cfu} / \mathrm{cm}^{2} \text { ) }\end{array}$ & $\begin{array}{l}\text { Initial microbial } \\
\text { load }\end{array}$ & $\begin{array}{l}\text { Final microbial } \\
\text { load }\end{array}$ & $\begin{array}{l}\text { Microbial load } \\
\text { change }\end{array}$ & $\begin{array}{l}\% \text { Reduction in } \\
\text { microbial load }\end{array}$ \\
\hline \multirow[t]{6}{*}{ Aluminium } & \multirow[t]{3}{*}{ NO } & \multirow[t]{3}{*}{6} & TVC & $5.60 \pm 1.16$ & $0.58 \pm 0.13$ & $5.02 \pm 1.12$ & 89.6 \\
\hline & & & TCC & $3.96 \pm 1.14$ & $0.63 \pm 0.34$ & $3.33 \pm 0.99$ & 84.1 \\
\hline & & & $\angle A B$ & $3.57 \pm 0.78$ & $0.18 \pm 0.09$ & $3.33 \pm 0.82$ & 93.3 \\
\hline & \multirow[t]{3}{*}{ YES } & \multirow[t]{3}{*}{6} & TVC & $6.15 \pm 0.59$ & $1.06 \pm 0.33$ & $5.10 \pm 0.60$ & 82.9 \\
\hline & & & TCC & $5.10 \pm 0.97$ & $0.78 \pm 0.11$ & $4.32 \pm 0.86$ & 84.7 \\
\hline & & & $\angle A B$ & $3.96 \pm 0.70$ & $0.08 \pm 0.04$ & $3.88 \pm 0.67$ & 98.0 \\
\hline \multirow[t]{6}{*}{ Plastic } & \multirow[t]{3}{*}{ NO } & \multirow[t]{3}{*}{24} & TVC & $5.97 \pm 1.11$ & $3.67 \pm 0.81$ & $2.30 \pm 0.61$ & 38.5 \\
\hline & & & TCC & $5.03 \pm 0.99$ & $3.37 \pm 0.81$ & $1.66 \pm 0.73$ & 33.0 \\
\hline & & & $\angle A B$ & $4.79 \pm 0.85$ & $2.63 \pm 1.08$ & $2.15 \pm 0.98$ & 44.9 \\
\hline & \multirow[t]{3}{*}{ YES } & \multirow[t]{3}{*}{24} & TVC & $6.02 \pm 0.98$ & $4.01 \pm 1.01$ & $2.01 \pm 0.68$ & 33.4 \\
\hline & & & TCC & $5.12 \pm 0.86$ & $3.92 \pm 0.71$ & $1.20 \pm 0.55$ & 23.4 \\
\hline & & & $\angle A B$ & $4.83 \pm 0.79$ & $2.86 \pm 1.06$ & $1.91 \pm 0.75$ & 39.5 \\
\hline
\end{tabular}

2004). Studies have shown that handling small quantities of milk is subject to a high rate of contamination with a small ratio of milk volume to container volume (Bonfoh et al., 2003). Despite plastic jerry cans being of greater risk to milk contamination, many dairy actors in Kenya prefer them for milk handling because they are cheaper than the aluminium cans as shown in Fig. 2 (Omore et al. 2005).
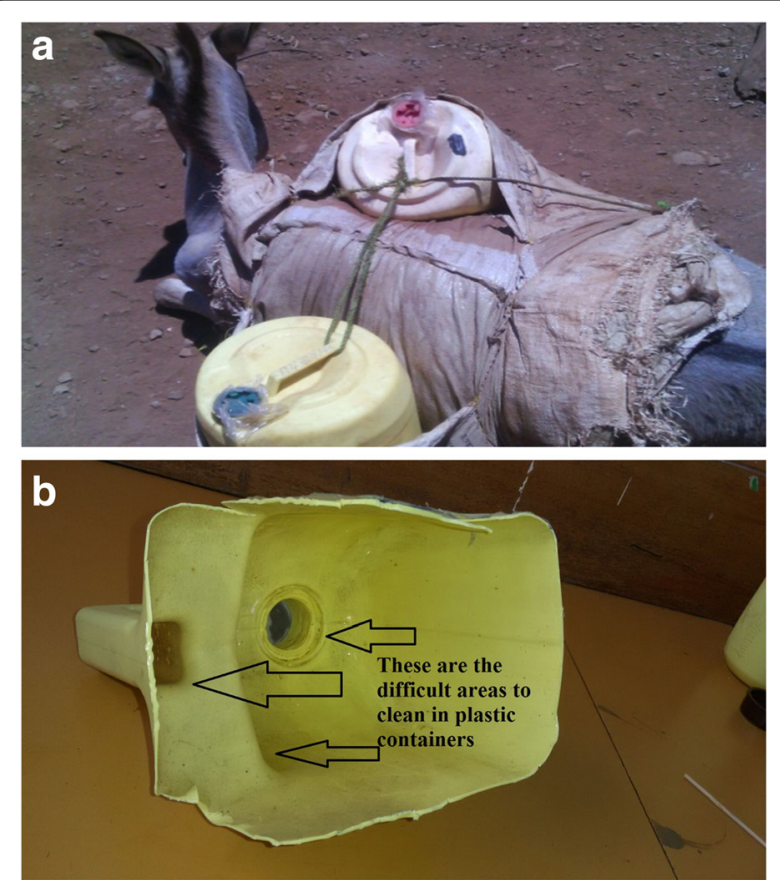

Fig. 2 a: Milk transportation in plastic jerry can containers using a donkey $\mathbf{b}$ : Cross-sectional view of inside the plastic container showing difficult areas to be cleaned
The temperature of the water to be used in the sanitation plays a big role in the efficacy of the process. Hot water was found to be the more effective against TVC and $\mathrm{LAB}$ reduction followed by cold water and the least was warm water. The TVC and LAB was reduced as a result of high temperatures of hot water that denatured the microbial cells and the antimicrobial activity of the soap. However, use of cold water with soap was more effective against TCC than the use of warm and cold water. Hence, increase in the temperature of water in the sanitation process causes reduction of the soap antimicrobial lethality against TCC. Also, irrespective of the water temperature used in the sanitation, the use of a scourer had significantly less reduction of TVC and TCC but did not differ significantly for the reduction of the $\mathrm{LAB}$ as compared to where it was not used. Generally the LAB, which are the Gram positive bacteria are the most susceptible to reduction than the TCC which are the Gram negative bacteria. Several reasons can explain the high prevalence of Gram negatives. First, the Gram-negative bacteria are innately resistant by virtue of their double membrane structure that prevents the disinfection agents from accessing the cell wall target or enzymatic inactivation of the cleaners (Russell 2001). Secondly is that the bar soap and the commercial scourer used in the cleaning are contaminated and introduce bacteria in the process. Earlier studies had found out bar soaps used in the sanitation were excessively colonized with bacteria which were predominantly Gram-negative bacteria (Zeiny 2009). The total viable count is for the overview of microbial contamination and total coliform count is for the evaluation of hygiene (Tamime 2009).

The scourer is used to offer mechanical abrasive energy to aid in detachment of bacteria from equipment surfaces, but some studies have shown that this mechanical scouring 
is then often insufficient (Bylund 1995). The scourer's abrasive forces cause scratches on the surface of the milk equipments thus facilitating the attachment and colonization of bacteria because roughness (Latorre et al. 2010). The abrasive force also causes wear of materials in the milking handling equipment that causes the appearance of cracks and crevices (Czechowski 1990). The energy required to remove deposit decreases with distance from the surface, suggesting that the cohesive forces between elements of the deposit are weaker than those of adhesion (Fryer et al. 2006).

From the study, the reduction of the microbial load was very low on the plastic jerry cans and the main reason was the nature of their material which was, first, hydrophobic thus exhibiting greater microbial surface adherence when compared with hydrophilic materials such as aluminium cans, glass and stainless steel (Sinde and Carballo 2000). Secondly, the surface texture and shape of equipments also determine the cleaning efficiency such as smooth surfaces are easier to clean than rough surfaces (Wirtanen et al. 1995).

\section{Conclusion}

Irrespective of the type of the water used (cold, warm or hot) and use or no use of commercial scourer in the sanitation process, microbial load reduction from plastic containers was very minimal compared to the aluminium cans. As a result, the uses of these plastic containers have high levels of milk contamination. Therefore, dairy actors should be encouraged to use food grade plastic containers, Mazican, in handling milk.

\section{Abbreviations \\ ANOVA, analysis of variance; BMBF, German ministry of education and research; GLM, general linear model; HDPE, high-density polyethylene; $L A B$, lactic acid bacteria; LSD, least significant difference; LST, Lauryl sulfate tryptose; MR, methyl-red; MRS, de Man Rogosa and Sharpe agar; PC, polycarbonate; PCA, plate count agar; PP, polypropylene; PVC, polyvinyl chloride; ReLOAD, reduction of post-harvest losses and value addition in east african food value chains; SAS, statistical analysis system; TCC, total coliform count; TVC, total viable count; UK, violet red bile agar; VP, voges-proskauer}

\section{Acknowledgement}

We also thank ReLOAD team members; Caroline M. Makau, Joy D. Orwa, Johnson K. Mwove, Samuel M. Nato, Olivier B. Kashongwe, Linnet W. Mwangi and Faith N. Ndunge for their assistance in field samples collection, laboratory samples analysis and data analysis.

\section{Funding}

This research work was supported financially by German Ministry of Education and Research (BMBF) through ReLOAD Project RELOAD: Reduction of PostHarvest Losses and Value Addition in East African Food Value Chains.

\section{Authors' contributions}

This research work was part of NW Thesis research for the award of MSc. Food Science degree of Egerton University and supervised by JM, JN, PL and WN was in charge of field samples collection and laboratory samples analysis under the directorship of the three supervisors. The supervisors were also involved in the designing of the experiment, data analysis, interpretation of the results and development of this manuscript. All authors read and approved the final manuscript.

\section{Authors' information}

Mr. Nobert Wafula is a graduate Student in the Department of Dairy and Food Science and Technology in Egerton University, Kenya, undertaking an MSc. Food Science. Mr. Wafula also holds a BSc. Food Science and Technology and a Diploma in Dairy Technology from the same university. He also has working experience in the dairy and food manufacturing industries in Kenya. Prof. Joseph Matofari and Dr. John Nduko are senior lecturers in the Department of Dairy and Food Science and Technology in Egerton University while Mr. Peter Lamuka is a lecturer at the Department of Department of Food Science, Nutrition and Technology, University of Nairobi, Kenya.

\section{Competing interests}

The authors declare that they have no competing interests.

\section{Author details}

'Department of Dairy and Food Science and Technology, Egerton University, P.O. Box 536-20115, Egerton, Kenya. ${ }^{2}$ Department of Food Science, Nutrition and Technology, University of Nairobi, P.O. Box 29053, Nairobi, Kenya.

Received: 18 April 2016 Accepted: 20 July 2016

Published online: 03 August 2016

\section{References}

Ahmad MM, Owni E, and Osman AO. Assessment of Microbial Loads and Antibiotic Residues in Milk Supply in Khartoum State, Sudan; 2015.

Azadnia PK, Khan Nazer AH. Identification of lactic acid bacteria isolated from traditional drinking yoghurt in tribes of Fars province. Iran J Vet Res. 2009; 10(3):235-40.

Bonfoh B, Wasem A, Traore AN, Fane A, Spillmann H, Simbé CF, Alfaroukh IO, Nicolet J, Farah Z, Zinsstag J. Microbiological quality of cows' milk taken at different intervals from the udder to the selling point in Bamako (Mali). Food Control. 2003;14(7):495-500.

Bonfoh B, Roth C, Traore AN, Fane A, Simbe CF, Alfaroukh IO. Effect of washing and disinfecting containers on the microbiological quality of fresh milksold in Barnako (Mali). Food Control. 2006;17(2):153-61.

Bylund G. Dairy Processing Handbook: Tetra Pak Processing Systems AB S 22186 Lund, Sweden; 1995.

Coorevits AN, Valerie DJ, Vandroemme J, Reekmans R, Heyrman J, Messens R, De Vos $P$, Heyndrickx L. Comparative analysis of the diversity of aerobic sporeforming bacteria in raw milk from organic and convectional dairy farms. Syst Appl Microbiol. 2008;31(2):126-40.

Czechowski MH. Bacterial attachment to Buna-a-gaskets in milk processing equipments. Aust J Dairy Tech. 1990;45(2):113-4.

Fadaei A. Bacteriological quality of raw cow milk in Shahrekord, Iran. Vet World. 2014; $7(4): 240-3$.

Faille C, Carpentier B. Food contact surfaces, surface soiling and biofilm formation. In: Fratamico PM, Annous BA, Gunther IV NW, editors. Biofilms in the food and beverage industries. Oxford, Cambridge, New Delhi: Wood head Publishing Limited; 2009. p. 304-30.

Fryer PJ, Christian GK, Liu W. How hygiene happens: Physics and chemistry of cleaning. May Int J Dairy Technol. 2006;59:76-84.

Fuentes E, Bogue J, Gómez C, Vargas J, Le Gal PY. Effects of dairy husbandry practices and farm types on raw milk quality collected by different categories of dairy processors in the Peruvian Andes. Trop Anim Health Prod. 2014; 46(8): :1419-26.

Gibson H, Taylor H, Hall K, Holah J. Effectiveness of cleaning techniques used in the food industry in terms of the removal of bacterial biofilms. J Applied Microbiol. 1999;87:41-8

Goberna M, Insam H, Klammer S, Pascual JA, Sanchez J. Microbial community structure at different depths in disturbed and undisturbed semiarid Mediterranean forest soils. Microb Ecol. 2005;50(3):315-26.

Grainger J, Hurst J, Burdass D. Basic Practical Microbiology: A Manual. The Society for General Microbiology; 2001.

Gran HM, Mutukumira AN, Wetlesen A, Narvhus JA. Smallholder dairy processing in Zimbabwe: the production of fermented milk products with particular emphasis on sanitation and microbiological quality. Food Control. 2002;13(3):161-8.

KEBS (Kenya bureau of standards). Raw Milk -specification KS EAS 67: 2007. Third Edition. Nairobi 2010

Kelly PT, O'Sullivan K, Berry DP, More SJ, Meaney WJ, O'Callaghan EJ, O'Brien B. Farm management factors associated with bulk tank total bacterial count in Irish dairy herds during 2006/2007. Ir Vet J. 2009;62:36-42. 
Kivaria FM, Noordhuizen JPTM, Kapaga AM. Evaluation of the hygienic quality and associated public health hazards of raw milk marketed by smallholder dairy producers in the Dar es Salaam region, Tanzania. Trop Anim Health Prod. 2006;38(3):185-94.

Latorre AA, Van Kessel JS, Karns JS, Zurakowski MJ, Pradhan AK, Boor KJ, Jayarao BM, Houser BA, Daugherty CS, Schukken YH. Biofilm in milking equipment on a dairy farm as a potential source of bulk tank milk contamination. J Dairy Sci. 2010;93:2792-802

Lindsay D, Brozel V, Mostert J, Holy A. Differential efficacy of a chlorine dioxidecontaining sanitizer against single species and binary biofillms of a dairyassociated Bacillus cereus and a Pseudomonas fluorescens isolate. J Appl Microbiol. 2002;92:352-61.

Millogo V, Sjaunja KS, Ouedrago GA, Agenas S. Raw milk hygiene at farms, processing units andlocal markets in Burkina. Faso. Food Control. 2010;21(7): 1070-4.

Murphy SC, Boor KJ. Trouble-shooting sources and causes of high bacteria counts in raw milk. Dairy Food Environ Sanit. 2000;20(8):606-11.

Olivier D, Moshoeshoe SL. Incidence of aerobic spoilage-and psychrotrophic bacteria in non-pasteurised and pasteurised bovine milk from Maseru. Medical Technology SA. 2012;26(2):22-7.

Ombarak RA, Elbagory AM. Bacteriological Quality and Safety of Raw Camel Milk in Egypt. Egyptian J Dairy Sci. 2014;42:95-103.

Omore A, Lore T, Staal S, Kutwa J, Ouma R, Arimi S, Kang'ethe E. Addressing the public health and quality concerns towards marketed milk in Kenya. Kenya: SDP Research and Development Report No. 3. Smallholder Dairy (R\&D) Project; 2005

Orregard M. Quality analysis of raw milk along the value chain of the informal milk market in Kiambu County, Kenya. Kenya: Thesis, Swedish University of Agricultural Sciences, Uppsala; 2013.

Reinemann DJ, Wolters GMVH, Billon P, Lind O. and Rasmussen MD. Review of practices for cleaning and sanitation of milking machines. BulletinInternational Dairy Federation. 2003: 3-18.

Reta MA, Bereda TW, Alemu AN. Bacterial contaminations of raw cow's milk consumed at Jigjiga City of Somali Regional State, Eastern Ethiopia. Int J Food Contam. 2016;3(1):1-9. doi:10.1186/s40550-016-0027-5.

Richardson GH. Standard Methods for the Examination of Dairy Products American Public Health Association. Washington, DC. 1985.

Russell AD. Mechanisms of bacterial insusceptibility to biocides. Am J Infect Control. 2001;29:259-61.

Salustiano VC, Nelio JA, Sebastiao CB, Willian M, Gabriela P. An assessment of chemical sanitizers on the microbiological profile of air in a milk processing plant. J Food Saf. 2004;24:159-67.

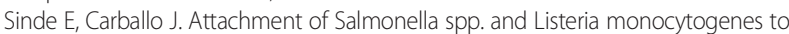
stainless steel, rubber and polytetrafluorethylene: the influence of free energy and the effect of commercial sanitizers. Food Microbiol. 2000;17:439-47.

Tamime AY. Milk Processing and Quality Management: Quality Control. Belleque J., Chicon R. and Recio I., Eds. West Sussex, UK: John Wiley and sons publishers; 2009. Pg 75

Tasci F. Microbiological and chemical properties of raw milk consumed in Burdur. J Anim Vet Adv. 2011:10(5):635-41.

Wafula NW, Matofari JW, Nduko JM and Lamuka PO. Sanitation practices used by dairy actors along the smallholder raw milk value chain and its effect on milk post-harvest losses in Kenya. African Journal of Food Science and Technology. InPress. 2016.

Welearegay H, Yilma Z, Tekle-Giorgis Y. Hygienic practices and microbiological quality of raw milk produced under different farm size in Hawassa, southern Ethiopia. Agric Res Rev. 2012:132-42.

Wirtanen G, Ahola H, Mattila Sandholm T. Evaluation of cleaning procedures in elimination of biofilms from stainless steel surfaces in open process equipment. Trans I Chem E. 1995;73:9-16.

Worku T, Negera E, Nurfeta A, Welearegay H. Milk handling practices and its challenges in Borana Pastoral Community, Ethiopia. Afr J Agric Res. 2014; 9(15):1192-9.

Zeiny SMH. Isolation of Some Microorganisms from Bar Soaps and Liquid Soaps in Hospital Environments Iraqi. J Pharm Sci. 2009:18(1):28.

\section{Submit your manuscript to a SpringerOpen ${ }^{\odot}$ journal and benefit from:}

- Convenient online submission

- Rigorous peer review

- Immediate publication on acceptance

- Open access: articles freely available online

- High visibility within the field

- Retaining the copyright to your article

Submit your next manuscript at $\gg$ springeropen.com 